\title{
Histone H3 Lysine 4
}

National Cancer Institute

\section{Source}

National Cancer Institute. Histone H3 Lysine 4. NCI Thesaurus. Code C107427.

The lysine residue found at amino acid position 4 in the histone $\mathrm{H} 3$ protein. Methylation of this residue may be a marker for transcriptionally active genes. 